\title{
The Status Quo and Strategy of Cross Border E-commerce Export Trade for Agricultural Products
}

\author{
Yu-Di SONG ${ }^{a}$, Yan DANG ${ }^{b}$, Cheng CHEN $^{\mathrm{c}, *}$ \\ College of Economics, Sichuan Agricultural University, Chengdu, China \\ a5193382116@qq.com, ${ }^{b} 517351886 @ q q . c o m,{ }^{c} 8521153 @ q q . c o m$
}

*Corresponding author

Keywords: Cross-border E-commerce, Agricultural exports, Fresh vegetables.

\begin{abstract}
In the past a few years, China officially opened some cross-border agricultural trade platforms, and now government is accelerating the development of them. In the case of the slow development of traditional agricultural trade and the deterioration of the trading environment, the development of cross-border E-commerce of agricultural products has achieved a lot in expanding agriculture products export, speeding up the adjustment of Chinese agricultural trade pattern, accelerating the transformation and upgrading of agricultural trade. This paper attempts to analyze the current situation and problems of cross-border E-commerce in agricultural export trade, and put forward the author's suggestion.
\end{abstract}

\section{Introduction}

In recent years, Chinese development in agricultural product cross-border E-commerce area can be said to be unstoppable, which including eBay, Amazon, Alibaba, Dunhuang network, Lanting and so on E-commerce platforms have begun to develop cross-border trade, so that Chinese cross-border trade in agricultural products has began to get substantial increase. According to the relevant data show that Chinese largest E-commerce platform for agricultural sales increased from 3.7 billion Yuan in 2010 to 80 billion Yuan last year, the average annual growth rate of $112.15 \%$. The raw and fresh meat, fruit and vegetables E-commerce in 2013 national fresh E-commerce transactions are high as 13 billion Yuan, an increase of 221\% in 2014 with 26 billion Yuan [1]. Chinese imports of agricultural products began to gradually become a new trend, Taobao Tmall, Jingdong Mall , No. 1 Shop, "I want to cross purchase" and other E-commerce platform have also begun to open overseas agricultural products trade E-commerce channel. For example, Shanghai Free Trade Area has also opened "cross-border", "bonded area shop.COM" two agricultural cross-border E-commerce platforms [2]. Chinese agricultural products import transactions grew rapidly. This paper attempts to analyze the current situation and problems of cross-border E-commerce in agricultural products export.

Chinese exports of cross-border E-commerce transactions have got a great development following so many agricultural cross-border E-commerce platforms being build. According to the China Electronic Commerce Research Center (100EC.CN) monitoring data, Chinese exports of cross-border E-commerce transactions of 4.5 trillion Yuan in 2015, an increase of 26\%. In the first half of 2016, Chinese B2B E-commerce service provider's revenue scale of 13.4 billion Yuan, an increase of $21.8 \%$, Alibaba ranked first, the market shared of $38.5 \%$, followed by Global Sources 4.5\%, HC 3.4\%, Shanghai Steel Union 2.9\%, focus on technology 2.2\% Global Market 1.4\%, business treasure $0.9 \%$, the other $46.2 \%$, and Chinese agricultural exports in 2016 amounted to $\$ 73$ billion, up 3.5\% [3]. Beijing Industrial and Commercial University professor points out that Chinese agricultural product in the import and export are becoming the new focus after books, clothing, 3C, and it is regarded as E-commerce Leader, especially the raw and fresh, fresh meat, fruit and vegetable E-commerce are even more attention to the 2016 export of agricultural products [4].

With the development of China, the agricultural cross-border E-commerce, consumers can through the platform of E-commerce (Tmaii International, Foreign Wharf, Taobao Global Purchase, Jingdong 
Global Purchase, etc.) and also from the self-E-commerce platform (Jumei Shop, VIP com shop, Suning overseas purchase, honey bud, etc multiple channels) to buy their own needs goods [5]. Consumer trading options become more and more diversified than before. The traditional vegetable export trade model is the first product and then marketing. And buyers and sellers have to face to face to buy [6]. In cross-border E-commerce, vegetable exports reduce circulation, so that the industrial chain and the ecosystem service chain have been improved, domestic and foreign buyers and sellers are more convenient, better able to do timely communication and trade .It can also get more profits for the exporter, for example, Among the total cost of vegetable exports, the cost of production is low, but each link increases the cost of exporting vegetables, which has lead to producers to earn lower profits. In addition, the amount of vegetable exports is relatively low. Unit use of transport costs and increased cost of sales, E-commerce can effectively reduce transaction costs and shorten trading hours [7]. The diversification of the vegetable export through E-commerce has further contributed to the development of neighboring countries' trade and the development of emerging markets, including emerging markets such as Southeast Asia, Russia, Brazil, India, Turkey and South Africa, bringing the original European and US markets Agricultural trade pattern began to loose, which will effectively reduce the competitive pressures of a single market, expanding market space [8].

The influences of cross-border E-commerce on agricultural products export trading are great and significant. But some problems are still needed to be pointed out: 1) credit problem, logistic issue and quality inspection and other export circulation system, especially for agricultural products cross-border electricity business transaction urgently need to improve [9]. 2) Homogeneous competition. Internet connection to the world, when you open the internet, too many similar products appear in front of you, many propaganda are almost the same, the trend of homogeneous competition is increasingly obvious [10]. 3) Cross-border electricity business development in the central is much better advanced and mature but in western regions is relatively backward in China, there is a large space to improve [11].

\section{Status Quo of Cross-border E-commerce Development of Agricultural Products}

\section{Status Quo of Cross-border E-commerce Enterprises}

Agricultural products cross-border E-commerce through B2B, B2C, and even C2C E-commerce model can finish direct transaction. It can effectively reduce the transaction links and intermediate costs, and weaken the trade brokers, agents role. Consumers can get quality and cheap abroad agricultural products, at the same time it can also accelerated the circle and shorten the time between consumers and farmers.

In recent years, Chinese agricultural cross-border E-commerce development can be said to be unstoppable, which includes such as eBay, Amazon, Alibaba, Dunhuang network, Lanting and so on E-commerce platform have begun to develop cross-border trade, so that Chinese cross-border trade in agricultural products began to have a substantial increase.

Between 2013 and 2014, Chinese imports of agricultural products began to gradually become a new trend. Taobao Tmall, Jingdong Mall , No. 1 shop, "I want to cross Purchase" and other E-commerce platform have also begun to open overseas agricultural products trade E-commerce channel, and Shanghai Free Trade Area has also opened "cross-border", "bonded area shop.COM" two agricultural cross-border E-commerce platform, Chinese agricultural products import transactions grew rapidly.

\section{Agricultural Products Cross-border E-commerce Export Trade Market and Scale}

Chinese Internet industry is gradual adoption to each household, and agricultural products trade information and service information began to gradually spread in the global market, followed by Amazon, E-bay and other E-commerce platform in the global emerging market are rapidly developing, They are leading Chinese exports of international trade in agricultural products. 
Wu Zhe, Huang Yingchuan (2013) clearly pointed out that Chinese cross-border E-commerce will be a strong competitor. according to Chinese Ministry of Commerce data, since 2008, cross-border E-commerce compound annual growth are more than 40 percent, and by 2011 Chinese foreign trade E-commerce annual growth rate has been more than $40 \%$. In the external environment, demand is weak, the export growth slowed down significantly .But Chinese foreign trade E-commerce is still able to reverse the situation Maintained a high speed of growth.

According to the China Electronic Commerce Research Center (100EC.CN) monitoring data, Chinese exports of cross-border E-commerce transactions of 4.5 trillion Yuan in 2015, an increase of 26\%.And Chinese agricultural exports in 2016 amounted to US \$ 72,612,181 thousand, up 3.5\%.

With more and more mature E-commerce, agricultural products E-commerce transactions are more and more. The diversification of the vegetable export through E-commerce has further contributed to the development of neighboring countries' trade and the development of emerging markets, including emerging markets such as Southeast Asia, Russia, Brazil, India, Turkey and South Africa, bringing the original European and US markets Agricultural trade pattern began to easy, which will effectively reduce the competitive pressures of a single market, expanding market space.

\section{Agricultural Products Cross-border E-commerce Category}

The Categories associated with agricultural products cross-border E-commerce dealings, there are mainly Tobacco, tea, tea, Chinese medicine, fresh, and other characteristics of agricultural products. Beijing Industrial and Commercial University professor points out that Chinese agricultural products in the import and export are becoming the new focus after books, clothing, 3C, and it is regarded as E-commerce Leader, and one of Raw and fresh, fresh meat, fruit and vegetable E-commerce are even more attention to the 2016 export of agricultural products.

According to the relevant data show that Chinese largest E-commerce platform for agricultural sales increased from 3.7 billion Yuan in 2010 to reach 80 billion Yuan last year, the average annual growth rate of 112.15\%; and the raw and fresh meat, fruit and vegetables E-commerce in 2013 national Fresh E-commerce transactions as high as 13 billion Yuan, an increase of 221\% in 2014 will reach 26 billion, an increase of 100\%.

\section{Chinese Development Trend of Cross-border Agricultural Products E-commerce}

\section{Increased Trading Volume of Agricultural Products Daily}

Chinese current agricultural products related to the E-commerce platform has more than 30,000, not only to usher in establishing a good shopping experience, at the same time ushered in the continuing consumption and driving related consumer groups. With more and more mature E-commerce platforms increase, the agricultural E-commerce transactions become more and more. It is expected that Chinese agricultural E-commerce transactions account for $5 \%$ of agricultural trade in the next five years after 2016, foreign export business in agricultural products account for $1 \%$.

\section{Agricultural Products Gradually Tend to Industrialization}

In the future, agricultural products will gradually become industrialized, such as industrial chain factories in the whole process become more and more standardized. Agricultural E-commerce will achieve "three production and one standard", accounting for more than $60 \%$ of the proportion of agricultural trade. Chinese agricultural products E-commerce gradually diversified trend, the function of agricultural trading platform are much more, such as trading function, display function, information function, export-oriented function, expanding the supply chain function, the financing function will be more manifested. After 5 To 10 years of efforts, Cold chain logistics effect will give full play: reducing costs, improving efficiency and the quality. It brings "new farmers" the new profit growth. At the same time, it can be online and offline opposition, online channels more diversified, here refers to the platform + self-integration of this innovative model. Under the channel refers to the 
community store, convenience store network and its electronic menu, smart dishes and other new formats.

\section{Problems on the Cross-border E-commerce of Agricultural Products}

\section{Cross-border Electricity Trading Platform Specialized in Agricultural Products Is Small Size, Lack of Brand Effect}

Although the development of cross-border electric business rapidly, there are well-known such as Alibaba, Taobao, Jingdong. But the professional agricultural products cross-border electricity business platform is not well known, such as Shun Feng preferred, Gu Deng electricity business, I buy a network, a acres of fields, etc., also need to increase publicity and promotion efforts.

Taobao is "Chinese characteristics" channel, in fact, according to the regional characteristics of the $\mathrm{f}$ food sales stores is to do a rearrangement and combination. This is the shopping guide. Any one of the local characteristics of the vegetable products, there are many shops for sale. Such as Yuyao, Yangmei, Qingyuan mushrooms and so on there are numerous shops are in the sale, but consumers are difficult to determine which is true, or not. Taobao evaluation system in the establishment of agricultural products is not enough.

\section{Homogeneous Competition}

Internet connected to the world, too many similar products appear in front of consumers, the trend of homogeneous competition is becoming increasingly evidently. Homogeneous competition has the following three areas.

Homogenization of Agricultural Products. The homogenization of agricultural products refers to the degree of similarity in the agricultural products perceived by consumers. The homogenization of agricultural products is reflected in two aspects: the material homogeneity, such as shape, color, taste and other physical characteristics. Second, cognitive homogeneity, consumers in the E-commerce platform to buy agricultural products in addition to feel its physical characteristics, but also from the business branding, packaging, publicity, service, description and other aspects of the product recognition know. When consumers can not understand the difference from these messages, cognitive homogeneity is produced.

Business Model Homogenization. Business model is the way to obtain competitiveness in the agricultural products business market, for sellers the business model is very important. Business model homogenization is difficult to stand out in the fierce competition.

Homogenization of Marketing Strategy. Agricultural products E-commerce business marketing strategy can generally be divided into several major categories: First, the price concessions strategy. Attract consumers through low prices. The specific form of price concessions, such as discount, is a single item of goods promotion, and full, it is focused on improving the consumer spending. Second is the package strategy. The invoicing strategy avoids the unbalanced psychology that consumers generate due to the extra costs of online shopping, which helps to improve the conversion rate of consumers.

\section{Market System is not Mature and Logistics Costs is high}

Chinese agricultural cross-border E-commerce trading platform is still in its infancy, in the market system construction, management, construction is not yet mature, and some speculative operators still exist. Chinese agricultural products in the realization of E-commerce website are still not a perfect product logistics system. In China, only a small number of agricultural E-commerce companies have their own set of logistics and distribution system, most agricultural E-commerce companies are working with third-party logistics companies, rather than the perfect agricultural logistics system, which led to high distribution costs, distribution speed is too slow. Another highlight of cross-border E-commerce is the high cost of logistics. Most agricultural products are of low value, but transportation costs are high, usually more than $100 \%$ of the cost of goods or more. 


\section{A Great Gap in Achieving Standardization}

In China, especially in west, Farmers carry out small-scale production, Planting technologies are differences, and because of this standardization of agriculture products exports have a certain gap. E-commerce is still in the development period, the government and relevant departments in the establishment the corresponding policy of E-commerce agricultural products is still in the exploratory stage, there are no uniform quality standards of agricultural products. The quality of Agricultural products in E-commerce products, packaging, transportation and other aspects. So to establish a comprehensive information platform and promote the development of agricultural E-commerce logistics is very important.

\section{Suggestions on Promoting Chinese Cross-border E-commerce of Agricultural Products export}

\section{Regional Governments, Agricultural Associations Play a Leading Role in Organization the Rural Small and Scattered Land to the Formation of Large-Scale Industrialization}

Industry associations to play a leading role in organizing small and scattered farmers, combined with the cross-border electricity business platform, effectively promote the industrialization of agriculture, market development, and promote more agricultural products to go out to improve the income of farmers.

The main reason for the high cost of production and export of some agricultural products in China is that the decentralized operation of small farmers restricts the use of large-scale operation and large-scale agricultural machinery, resulting in the production efficiency is not high. If the small farmers can become large, small household business into a large farmer and agricultural park business model, coupled with self-built professional cross-border E-commerce platform, will become an important force to promote the development of Chinese agricultural production. Such as Xintai City, Shandong Province Tianbao town has a "Chinese cherry first town" reputation, with the Culai mountain acres of cherry base to create, regional cherry production of large farmers gradually integrated into the cherry production cooperatives. Now with the cross-border electricity business platform, cooperatives cherry quickly opened the situation in Japan and South Korea market, not only the price of electricity to the market price of 3 to 5 Yuan per catty, and cross-border trade process savings costs are also very impressive [11].

\section{Focus on Cultivating and Building Agricultural Products Specialized Cross-border Electricity Business Platform, the Formation of Large Brand Effect}

At present, Gu Deng electricity cross-border platform is more professional in agricultural product. After years of exploration and growth, which Gu Deng electricity business development and growth and under the line of agricultural wholesale market for the traditional agricultural market to bring modern Internet technology and innovation, for farmers passive, no channel of the status quo, Began to supply more farmers for the origin of agricultural products and farmers in the market batch of thousands of farmers to build a platform to face to face communication, do not need to match the matchmaking, directly to their own agricultural products on display to the farmers, zero distance exchange establish a trust relationship in order to facilitate the development of a stable channel of trade cooperation.

\section{Establishment of A Unified Agricultural Products Cross-border Electric Business Export System}

In view of Chinese agricultural cross-border E-commerce transactions when the trust, the standard unified E-commerce credit system is necessary. In Chinese E-commerce platform system, we must do a unified credit information collection, sharing and use mechanism, such as Eastern Airlines began to take advantage of its logistics advantages to actively participate in cross-border E-commerce services, the establishment of "Eastern Airlines origin direct", compatible with b2b and b2c model, fresh food, vegetables and fruit products and overseas procurement and domestic sales. Although the "East 
China Sea origin direct" focus on the import of foreign agricultural products, but if the platform for domestic agricultural exports, will significantly enhance the export of agricultural products, the level of professional logistics and logistics efficiency, thereby reducing the logistics costs of agricultural exports and shorten the logistics time.

\section{Construction of Intelligent Logistics, the Use of E-Commerce Train, Cold Chain Car}

On the logistics problem, the logistics cost is too high is the root cause of asymmetric information on the road more than $40 \%$ of the trucks are empty, to solve this problem must establish information platform, building intelligent logistics. And can use E-commerce special train, cold chain car instead of the current logistics model. It is understood that in August 2015, the first E-commerce train opened, each train 15-19 cars, each car loaded 23 tons, loading the equivalent of 629.6 meters long truck, or 36 Boeing 737 freighters capacity.

\section{Acknowledgement}

This work was financially supported by the Undergraduate Thesis Breeding Program of Sichuan Agricultural University (2015).

\section{References}

[1] G. Yang, Conception of comprehensive market of agricultural products based on E-commerce, Reform and Opening-up 11 (2009) 100-100.

[2] X. Li, G.S. Zhang, D,C. Luo, Analysis on the problems and countermeasures of developing agricultural products trade by e-commerce, Agricultural Economy 12 (2005) 25-26.

[3] H.P. Peng, Research on transaction cost of E-commerce of agricultural products, Journal of Yangtze University 4 (2008) 115-117.

[4] X. Chen, J.X. Cui, J.J. Lin, On the application of electronic commerce in china 's agricultural trade, Technology and Innovation Managemen 4 (2009) 445-446.

[5] Information on http://www.100ec.cn/zt/upload_data/B2B/1516ckbg.pdf.

[6] L. Ma, Application problems and countermeasures of E-commerce in china 's agricultural trade, Business economy 11 (2013) 2-3.

[7] J.H. Tang, The feasibility demonstration of the application of E-commerce in agricultural trade based on SWOT model-a case study of xinjiang agricultural products E-commerc, Business economy 3 (2014) 32-33

[8] W.W. Zhang, X.B. Zhang, Opportunities and countermeasures of cross-border E-commerce transactions of Guizhou characteristic agricultural products, Observation 12 (2015) 7-8.

[9] R.D. Banker, S. Mitra, Procurement models in the agricultural supplychain: A case study of online coffee auctions in Ind, Electronic Commerce Research and Applications (2007) 309-321.

[10]N. Norbert, Q. Thomas, K. Sibylle, Information and its man-agement for differentiation of agricultural products: The example of specialty coffee, Computers and Electronics in Agriculture 61 (2008) 241-253.

[11]Y.H. Cui, Analysis on the way to reduce the cost of agricultural products export by cross-border E-commerce, Foreign Trade Practice (2015)15-16. 